\title{
Ground Water in Hawaii
}

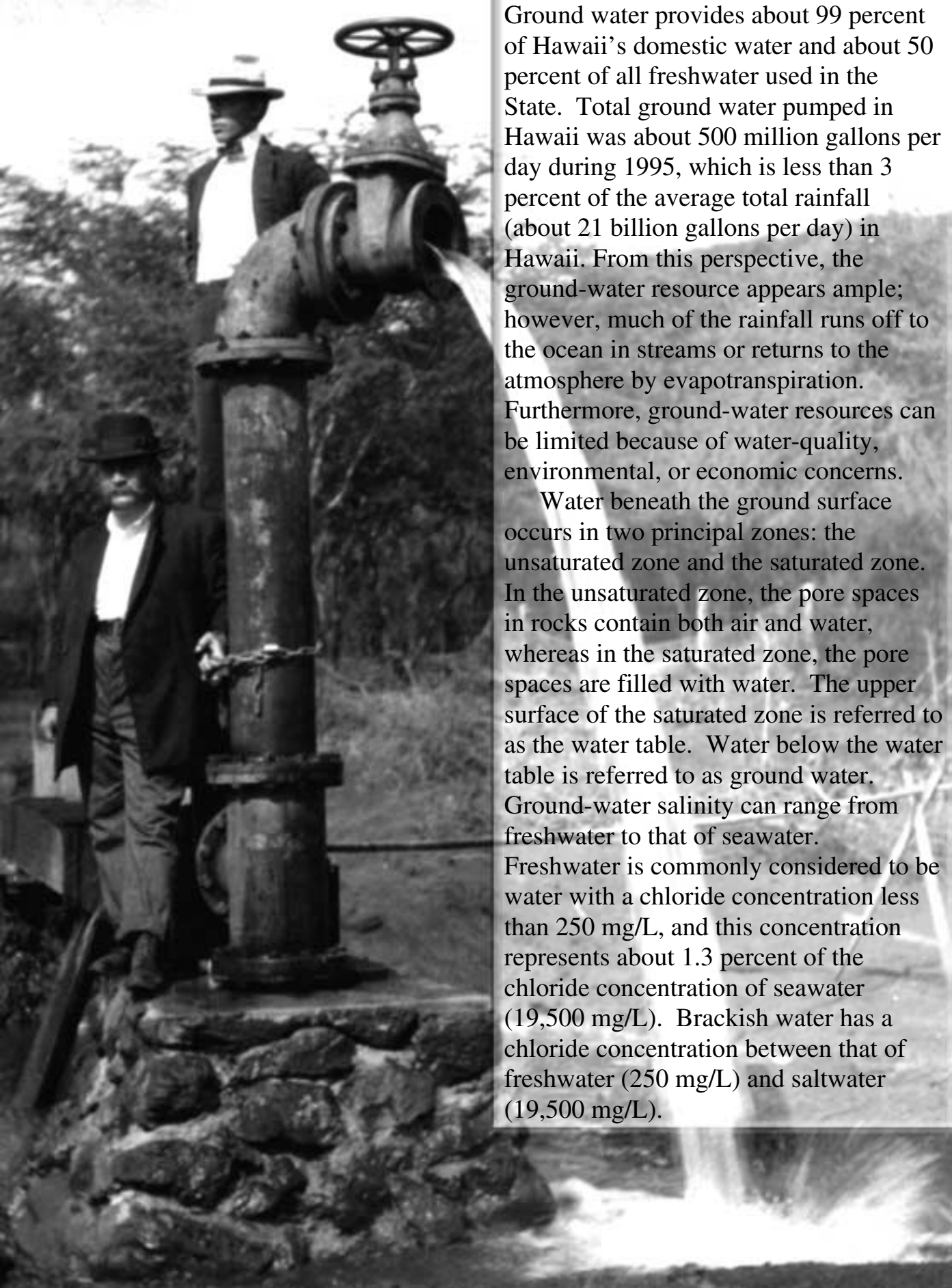

Ground water is one of Hawaii's most important natural resources. It is used for drinking water, irrigation, and domestic, commercial, and industrial needs. Ground water provides about 99 percent of Hawaii's domestic water and about 50 percent of all freshwater used in the State. Total ground water pumped in Hawaii was about 500 million gallons per day during 1995, which is less than 3 percent of the average total rainfall (about 21 billion gallons per day) in Hawaii. From this perspective, the ground-water resource appears ample; however, much of the rainfall runs off to the ocean in streams or returns to the atmosphere by evapotranspiration. Furthermore, ground-water resources can be limited because of water-quality, ironmental, or economic concerns. Water beneath the ground surface occurs in two principal zones: the unsaturated zone and the saturated zone. In the unsaturated zone, the pore spaces in rocks contain both air and water, whereas in the saturated zone, the pore spaces are filled with water. The upper surface of the saturated zone is referred to as the water table. Water below the water table is referred to as ground water. Ground-water salinity can range from freshwater to that of seawater.

Freshwater is commonly considered to be water with a chloride concentration less than $250 \mathrm{mg} / \mathrm{L}$, and this concentration represents about 1.3 percent of the concentration of seawater $(19,500 \mathrm{mg} / \mathrm{L})$. Brackish water has a freshwater $(250 \mathrm{mg} / \mathrm{L})$ and saltwater 19,500 mg/L).

\section{GROUND-WATER RECHARGE}

The amount of recharge available to enter the aquifers is the volume of rainfall, fog drip, and irrigation water that is not lost to runoff or evapotranspiration or stored in the soil. Rainfall is spatially variable because of the islands' topography and the persistent northeasterly tradewinds. In dry areas, annual rainfall is less than 10 inches; in wet areas, annual rainfall is greater than 400 inches. In general, southwestern, leeward sides of the islands are driest and northeastern, windward sides are wettest. Fog drip, which is cloud vapor that is intercepted by vegetation and subsequently drips to the ground, commonly occurs between altitudes of 2,000 and $6,000 \mathrm{ft}$.

Recharge is typically about 10 to 50 percent of the rainfall, fog drip, and irrigation water. Runoff is directly related to factors including rainfall, topography, soil type, and land use. Runoff is typically about 10 to 40 percent of rainfall, but is higher where rainfall is high and slopes are steep and where rain falls on poorly permeable land surfaces. Evapotranspiration is the loss of water to the atmosphere by the combination of transpiration of plants and direct evaporation from land and water surfaces and can exceed 50 percent of rainfall. Water stored in the soil is available for plants or can eventually flow downward to recharge the aquifer.

Large-scale development of ground water in Hawaii began after the first successful well was drilled in 1879 in southern Oahu. The well shown, drilled in 1909 near Pearl Harbor, derives its water from a volcanic-rock aquifer that is confined by overlying sedimentary deposits. This well is an artesian well because it taps a confined aquifer, and is free flowing because the pressure in the aquifer is sufficient to raise the water above the land surface. 


\section{HYDROGEOLOGY}

The most extensive and productive aquifers in the Hawaiian islands are formed by volcanic rocks that erupted during the principal building stage of each volcano. Lava from this stage, called the shield stage, consists of basalts that characteristically form thin flows ranging in thickness from a few feet to a few tens of feet. The shield stage is the most voluminous phase of eruptive activity during which 95 to 98 percent of the volcano is formed. Thousands of lava flows erupt from the central caldera of the volcano and from two or three rift zones that radiate out from the caldera. Intrusive dikes fed by rising magma extend down the rift zones and may erupt if they reach the surface. Some volcanoes have a postshield-stage during which lava flows over the shield-stage basalt. The post-shield stage lava flows are marked by a change in lava chemistry and character that commonly leads to the formation of massive lava flows that can be many tens of feet thick. After a period of volcanic inactivity, lava might issue from isolated vents on the volcano during a final, rejuvenated stage.

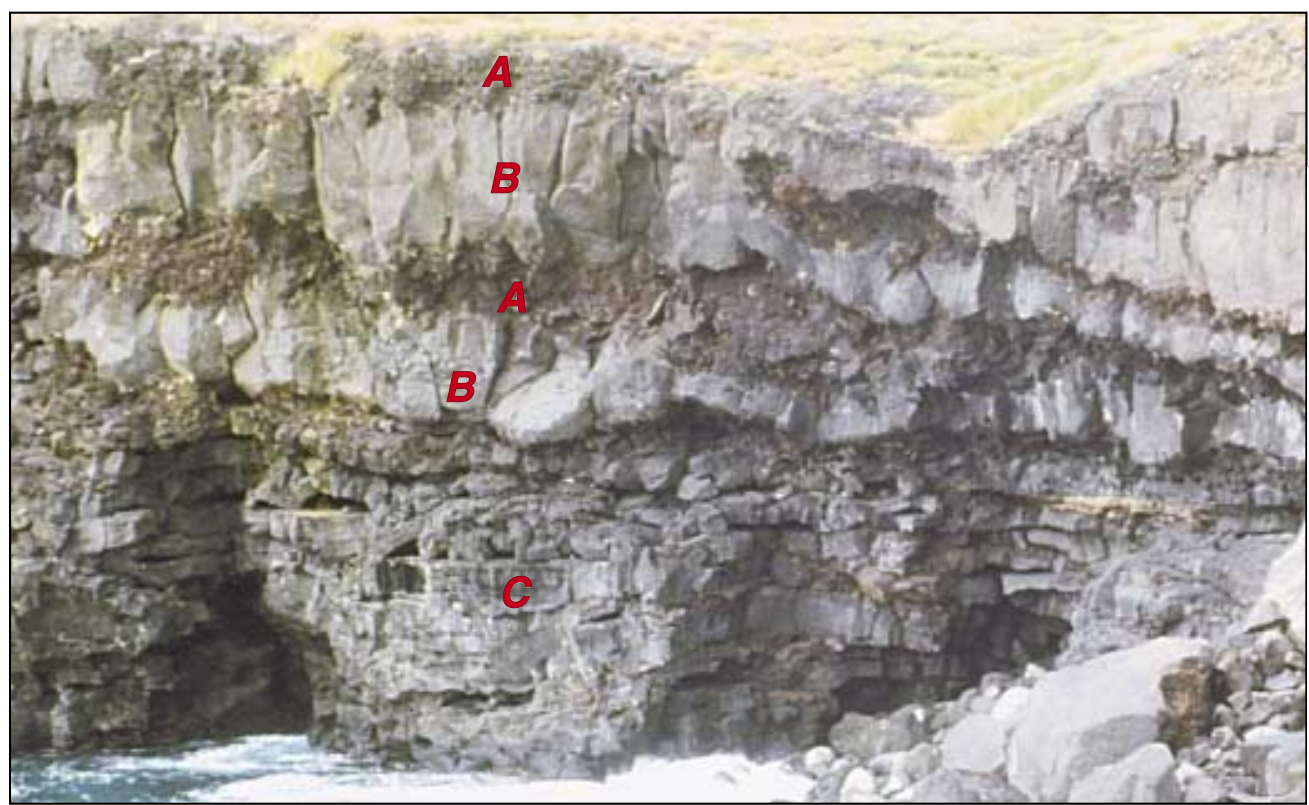

A typical sequence of lava flows contains a clinker zones $(\boldsymbol{A})$ of relatively high permeability that occur above and below the massive central cores of a flows (B), and many thin pahoehoe flows (C). The sequence shown is about 50 feet thick. (photo by Scot K. Izuka, USGS). lava in the core of an aa flow typically cools as a massive body of rock with much lower permeability. The most productive and most widespread aquifers consist of thick sequences of numerous thin lava flows.

Dikes are thin, near-vertical sheets of massive, low-permeability rock that intrude existing rocks, commonly permeable lava flows. Dikes can extend vertically and laterally for long distances and impede the flow of ground water. Dikes can intersect at various angles and compartmentalize the more permeable rock in which ground water can be impounded. The dikes lower overall rock porosity and permeability.

Pyroclastic rocks include ash, cinder, spatter, and large blocks. Compaction and weathering can reduce the permeability; weathered ash beds commonly act as thin confining units within lava sequences.

Volcanic-rock aquifers are found throughout the eight major islands and are locally overlain by sedimentary deposits. Sedimentary deposits of alluvium, coralline limestone, and cemented beach or dune sand that typically are considered to be productive aquifers in much of the conterminous United States are relatively poor aquifers in the Hawaiian islands. Limestone deposits are highly permeable in many places and usually yield brackish water or saltwater because of good hydraulic connection between the ocean and the limestone and because of low recharge to the limestone.

In some places, weathered volcanic rocks or sedimentary deposits form a low-permeability confining unit overlying high-permeability volcanic rocks. In coastal areas, confining units of weathered volcanic rocks and sedimentary deposits are called caprock, which impedes the discharge of freshwater to the ocean. Confining units are also found in non-coastal areas, separating the volcanic rocks of two different volcanoes. Valley-filling sedimentary deposits generally are also of low permeability and can impede the seaward and lateral movement of ground water.

\section{Hawaii District web site - http://hi.water.usgs.gov}




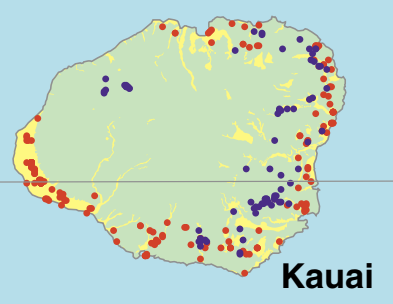

Niihau

\section{EXPLANATION}

\section{Volcanic-rock aquifer-Yellow where overlain by sedimentary deposits}

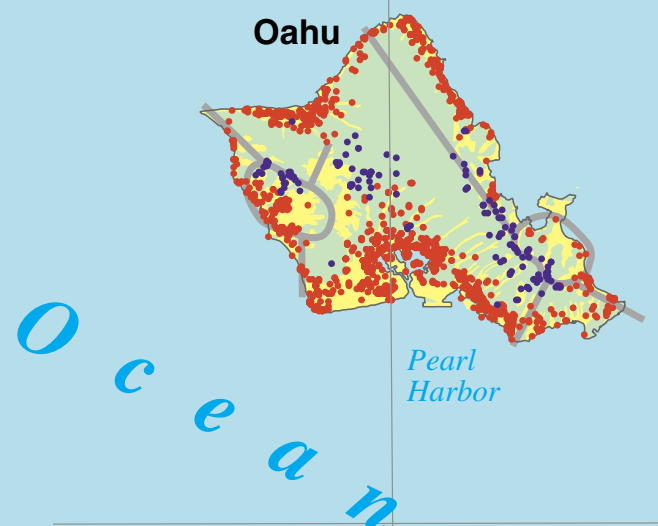

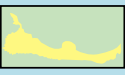

-

\section{Axis of rift zone- or caldera boundary-Approximately located}

Well with water level less than 50 feet above sea level

Well with water level greater than 50 feet above sea level

$\begin{array}{lll}0 & 20 & 40 \\ 0 & 20 & \text { MILES } \\ 0 & \text { 40 KILOMETERS }\end{array}$

\section{WHAT ARE THE GROUND-WATER SETTINGS IN HAWAII?}

In Hawaii, the major fresh groundwater systems are below the lowest water table, and are either freshwater-lens or dike-impounded systems. Where freshwater-lens and dike-impounded systems are adjacent, they form a single, hydrologically connected ground-water flow system. Minor perched systems can exist above the lowest water table.

\section{Freshwater-Lens System}

A freshwater-lens system includes a lens-shaped freshwater body, an intermediate transition zone of brackish water, and underlying saltwater. The transition zone can be quite thick (several tens to hundreds of feet) depending on the extent of mixing between freshwater and saltwater. Freshwater-lens systems are found in dike-free volcanic rocks and sedimentary deposits under confined or unconfined conditions. The most important sources of ground water in
Hawaii are from the freshwater parts of these systems in volcanic rocks.

In general, for a given aquifer permeability, low recharge results in low water levels and a thin freshwater lens. For a given recharge rate, low aquifer permeability results in high water levels and a thick freshwater lens. In the most permeable volcanic rocks, the water table is no more than a few feet above sea level, and the slope of the water table is nearly flat. In some low-permeability volcanic-rock aquifers, such as in eastern Kauai and northeastern Maui, a vertically extensive freshwater-lens system has freshwater extending from below sea level to the water table that is several hundreds or even thousands of feet above sea level. Dikes may intrude the lowpermeability rocks, but a vertically extensive freshwater-lens system can exist in areas that are dike free.

Meinzer (1930) defined water below the lowest water table as basal ground water to distinguish it from perched water. According to this broad definition, ground water in freshwaterlens and in dike-impounded systems both can be considered basal ground water. Descriptions of ground water in Hawaii have generally limited the use of the term "basal" to occurrences of ground water with a water table near sea level in highpermeability rocks, although Meinzer's definition of basal ground water was not so restrictive. Ground water in vertically extensive freshwater-lens systems can also be considered basal ground water using Meinzer's definition.

Freshwater-lens systems are recharged by direct infiltration of precipitation and irrigation water, and by inflow from upgradient ground-water systems. Discharge from freshwater-lens systems in highly permeable rocks is by diffuse seepage near the coast and to subaerial and submarine coastal springs. In a vertically extensive freshwater-lens system, much of the fresh ground water discharges directly to stream valleys above sea level where the ground surface intersects the water table. In highly 
The occurrence of fresh ground water in each of the Hawaiian islands can be depicted using water levels measured in wells. Water levels less than 50 feet above sea level were arbitrarily chosen to show occurrences of thin freshwater lenses. Water levels greater than 50 feet above sea level were chosen to show areas where vertically extensive freshwater-lens systems or dike-impounded water exist. Non-dike-intruded areas containing wells that penetrate below sea level and that have high water levels are considered to have vertically extensive freshwater-lens systems. Where high water levels are found in wells that do not penetrate below sea level, the possibility of a perched-water system cannot be ruled out. Although many of the ground-water systems of the islands are well understood, exploration in others that are not well understood is only just beginning.

Kauai has a large area with high water levels along the eastern side of the island. High water levels in wells that penetrate below sea level outside of any known rift zone indicate that a vertically extensive freshwater-lens system is present. Niihau receives little rain and data from existing wells indicate that a thin freshwater lens is present.

A large number of wells on Oahu in nearshore areas around most of the periphery of the island have low water levels. High water levels are found in rift zones near the eastern and western sides of the island and low-permeability features create high water levels in the central part. Some small areas of perched water in the southern part of Oahu are in alluvial deposits, but the perched water is not a significant source of supply.

In the northern part of Molokai, areas of high water levels are found in the northwest rift zone of East Molokai Volcano. Lanai has high water levels in the interior of the island near the rift zone and caldera complex. Few wells exist on Kahoolawe but because rainfall is low, the freshwater lens is probably thin.

The central isthmus and most of the coastal areas of Maui have low water levels indicative of a thin freshwater lens. High water levels are found in the interior of West Maui Volcano where rocks are intruded by dikes. On East Maui Volcano, high water levels are found along the northern flanks of the volcano in the high rainfall areas. Where high and low water levels occur together, a perched-water system exists above a freshwater lens. Farther to the east, high water levels are found in wells drilled below sea level indicating that a vertically extensive freshwater-lens system is present.

The island of Hawaii contains high water levels in the rift zones of Kilauea and Kohala Volcanoes. High water levels, possibly associated with a buried rift zone of Hualalai Volcano or fault scarps draped with lava flows, also are present along the western coast. Areas of high water levels also are found along the northern flank and eastern flanks of Mauna Kea and on the southeastern flank of Mauna Loa. These high water levels are not fully understood.

permeable rocks, freshwater flow is mainly horizontal and toward the coast, but in low-permeability rocks, vertical flow can be significant.

Where confining units impede discharge of ground water, the freshwater lens is thicker than it would be without confinement. Caprock confining units impede the discharge of ground water to the ocean in southern Oahu, central Maui, and western Kauai. Salinity of ground water in the caprock is variable and this water is considered part of the freshwater-lens system. In some places, weathered volcanic-rock confining units impede the flow of ground water between a lower volcanic-rock aquifer and an upper volcanic-rock aquifer. Confined freshwater in the lower aquifer can be overlain by brackish water in the upper aquifer. This type of layering in a freshwater-lens system occurs in eastern Hawaii where a confining unit on the surface of the older rocks of Mauna Kea Volcano underlies the younger rocks of Mauna Loa Volcano. 

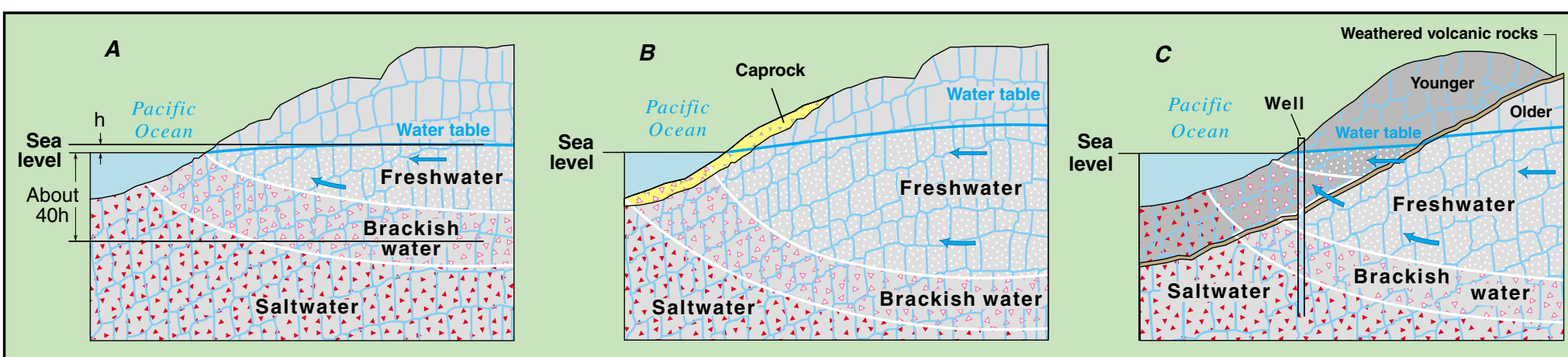

On oceanic islands, such as the Hawaiian islands, freshwater commonly occurs as a body of water called a freshwater lens that floats on saltwater and is separated from the saltwater by a transition zone of brackish water. (A) The Ghyben-Herzberg principle is commonly used in Hawaii to estimate the depth where the brackish water in the transition zone has a salinity about 50 percent that of seawater. The Ghyben-Herzberg principle is named after two scientists who independently described a freshwatersaltwater relation for conditions in which the two fluids do not mix (no transition zone) and the freshwater flow is predominantly horizontal. For these conditions, the freshwater-lens thickness below sea level is directly proportional to the height of the top of freshwater above sea level. In principle, at a place where the water table stands 1 foot above sea level, for example, 40 feet of freshwater will be below sea level, and the freshwater lens will thus be 41 feet thick. This relation exists because seawater is about one-fortieth more dense than freshwater. In a real freshwater-lens system, mixing creates a transition zone and reduces the amount of freshwater above the transition zone. In some places where freshwater is extensively mixed with saltwater, brackish water may exist immediately below the water table. (B) Where low-permeability caprock acts as a confining unit near the coast, a thicker freshwater lens develops

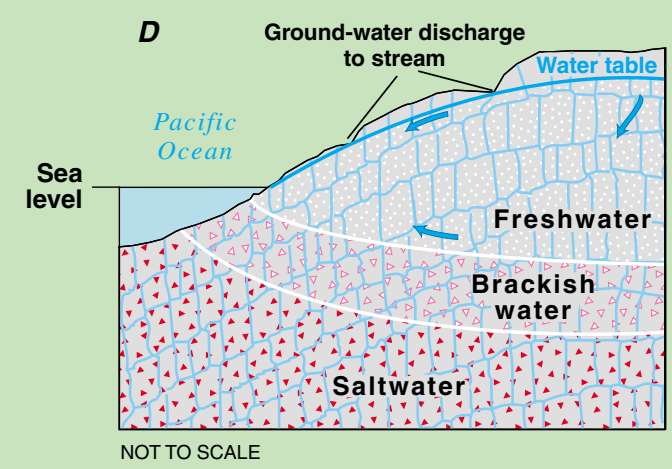
because ground water cannot discharge as readily to the ocean. The Ghyben-Herzberg principle applies where flow is predominantly horizontal. (C) Weathered volcanic rocks on the surface of an older volcano form a confining unit between the lower and upper aquifers. The well penetrates freshwater underlain by brackish water. Beneath the confining unit, the well penetrates deeper freshwater underlain by brackish water and saltwater. Fresh ground water flows from the deeper volcanic-rock aquifer through the confining unit into the upper volcanic-rock aquifer. (D) In systems where low-permeability rocks cause significant vertical hydraulic-head gradients, the Ghyben-Herzberg principle does not accurately predict the depth where the brackish water in the transition zone has a salinity about 50 percent of seawater. Although the depth to saltwater has not been measured in wells in these systems, where flow is downward, the freshwater lens is likely thinner than predicted by the Ghyben-Herzberg principle.

\section{Dike-Impounded System}

A dike-impounded system is found in the rift zones and caldera of a volcano where low-permeability dikes have intruded other rocks. The flow system includes the freshwater body, and where it exists, the underlying brackish water and saltwater. Near-vertical dikes tend to compartmentalize areas of permeable volcanic rocks. Dikes impound water to heights as much as 3,300 feet above sea level on the islands of Maui and Hawaii and as much as 1,600 feet above sea level on Oahu. The depth to which freshwater extends below sea level within a dike- impounded system is not known in places with high water tables. Where few dikes intrude permeable volcanic rocks, the water table may be only a few feet to a few tens of feet above sea level and saltwater has been found below the freshwater.

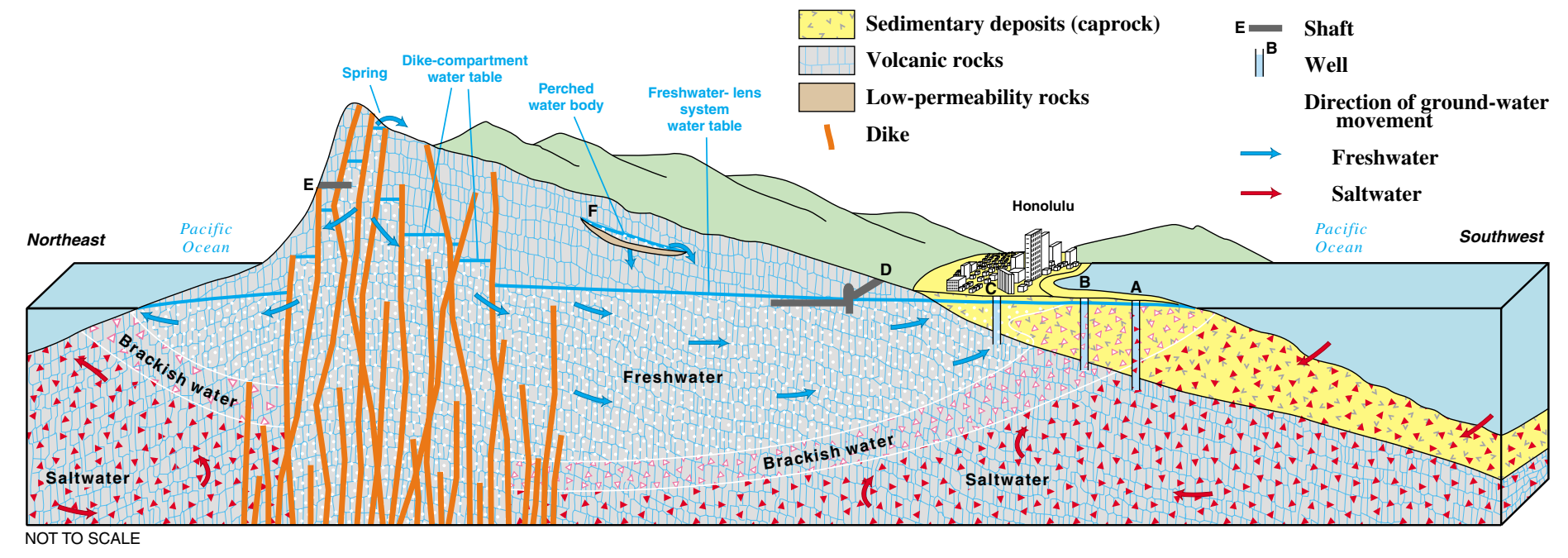

Fresh ground water generally moves from topographically high areas towards the ocean. Fresh ground-water flow is generally downward in the inland areas, upward in the coastal areas, and horizontal in between. A saltwater circulation system exists beneath the freshwater lens. Saltwater flows landward in the deeper parts of the aquifer, rises, then mixes with fresher water and discharges to the ocean.

A freshwater-lens system underlies much of southern Oahu. Well A produces saltwater from below the transition zone, well $\mathbf{B}$ produces brackish water from the transition zone, and well $\mathbf{C}$ produces freshwater.
Horizontal shaft D (sometimes called a Maui shaft) produces large volumes of freshwater by skimming water from near the top of the freshwater lens. Shaft $\mathbf{E}$ (sometimes called a Lanai shaft) is dug horizontally into one or more of the dike-bounded compartments. Location $\mathbf{F}$ indicates a perched water body containing minor amounts of water. 
Where erosion has exposed dike compartments in stream valleys such as in windward Oahu, ground water can discharge directly to the streams. In other areas, fresh ground water in dikeimpounded systems can discharge to downgradient ground-water systems or directly to the ocean.

\section{Perched System}

Perched water is found in areas where low-permeability rocks impede the downward movement of ground water sufficiently to allow a perched water body to develop within otherwise unsaturated rocks. These lowpermeability rocks include massive, thick-bedded lava flows, extensive soil and weathered ash layers, and sedimentary deposits. The areal extent and distribution of these rocks is highly variable. The height of the water table above sea level depends on the altitude of the low-permeability rocks and the rate and duration of recharge, and the extent of the perched system depends on the areal extent of the low-permeability rocks. Discharge from a perched system can be to springs, streams, the ocean, downward to a lower water table, or to the atmosphere by evaporation.

\section{WHAT LIMITS GROUND-WATER AVAILABILITY?}

The main factors limiting groundwater availability in the State of Hawaii are saltwater intrusion, the reduction of discharge to streams and the ocean, and lowering of water levels.

When water is withdrawn from a freshwater lens, the freshwater lens shrinks and saltwater or brackish water will intrude upward and landward into parts of the aquifer that formerly contained freshwater. The degree of saltwater intrusion depends on several factors, which include the hydraulic properties of the rocks, recharge rate, pumping rate, and well location. The effect of intrusion on a particular well depends on the vertical and lateral distance between the well and the transition zone. Wells completed in the freshwater lens near the coast are particularly likely to induce brackish water or saltwater movement into the well as pumping continues. Saltwater- intrusion problems can be minimized by appropriately locating wells and by controlling withdrawal rates.

In the Honolulu area of Oahu, some wells that originally produced fresh ground water were later abandoned because of increased salinity due to saltwater intrusion. Pumping from a well can cause the freshwater-saltwater transition zone to rise into the pumped well. Many wells in Hawaii that are pumped at high rates or drilled too deeply are affected by this process, resulting in increased sodium and chloride concentrations in pumped water.

Ground-water withdrawal ultimately reduces the amount of discharge to springs, streams, or the ocean by the amount that is withdrawn. Reduction of springflow and streamflow is a concern for several reasons, including loss of habitat for native aquatic species, reduced water supply for agricultural diversions, aesthetics, and recreational use. Reduced flow to the ocean may affect marine habitat and aquaculture practices in coastal fishponds.

Ground-water withdrawal also lowers water levels around the pumped well. Nearby wetlands and ponds may shrink or dry up causing loss of habitat for aquatic species. Discharge from nearby flowing wells may decrease or stop if water levels are lowered sufficiently.

\section{Additional Reading:}

This fact sheet is based on the publication Oki, D.S., Gingerich, S.B., and Whitehead, R.L., 1999, Hawaii in Ground Water Atlas of the United States, Segment 13, Alaska, Hawaii, Puerto Rico, and the U.S. Virgin Islands: U.S. Geological Survey Hydrologic Investigations Atlas 730-N, p. N12-N22, N36.

http://sr6capp.er.usgs.gov//gwa/gwa.html

\section{REFERENCES}

Hunt, C.D., Jr., 1996, Geohydrology of the island of Oahu, Hawaii: U.S. Geological Survey Professional Paper 1412-B, 54 p.

Izuka, S.K., and Gingerich, S.B., 1998, Ground water in the southern Lihue Basin, Kauai, Hawaii: U.S. Geological Survey Water-Resources Investigations Report 98-4031, $71 \mathrm{p}$.

Macdonald, G.A., Abbott, A.T., and Peterson, F.L., 1983, Volcanoes in the sea:

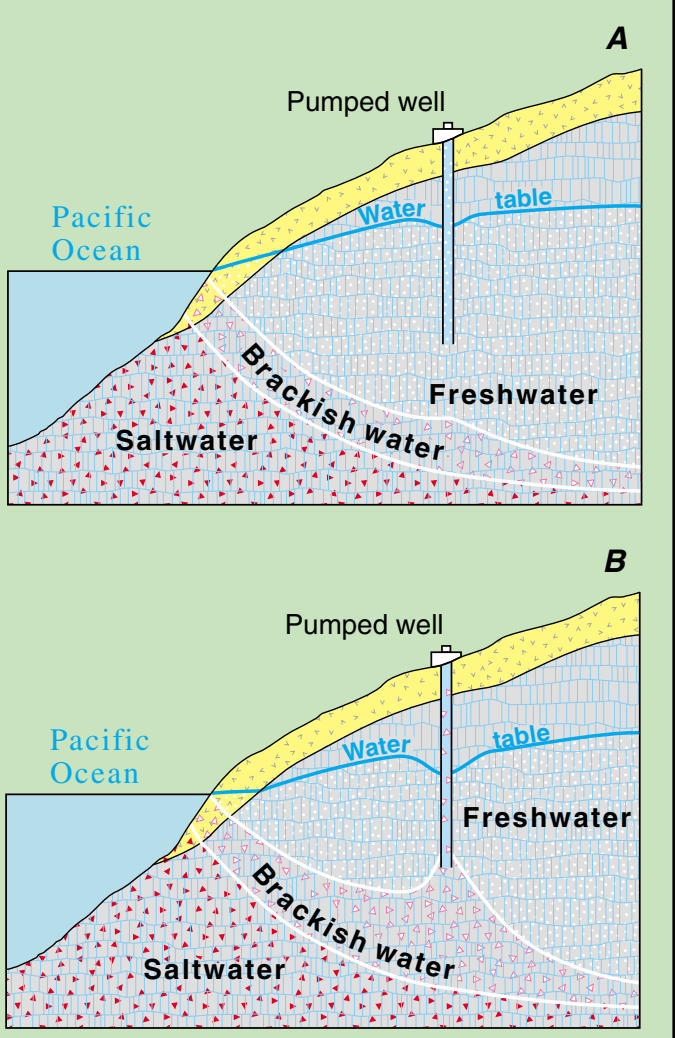

NOT TO SCALE

Saltwater intrusion is a potential problem near the coast. (A) Diagram of a well completed in a volcanic-rock aquifer in which withdrawal is small. Only limited saltwater intrusion has taken place. (B) Diagram of the same well under conditions of large ground-water withdrawal. Pumping has lowered the water table and caused the freshwater lens to thin. Brackish water has reached the well.

The geology of Hawaii ( $2 \mathrm{~d}$ ed.): Honolulu, Hawaii, University of Hawaii Press, $517 \mathrm{p}$.

Meinzer, O.E., 1930, Ground water in the Hawaiian Islands in Geology and water resources of the Kau District, Hawaii: U.S. Geological Survey Water-Supply Paper 616, p. 1-28.

Takasaki, K.J., and Mink J.F., 1985, Evaluation of major dike-impounded ground-water reservoirs, island of Oahu: U.S. Geological Survey Water-Supply Paper 2217, $77 \mathrm{p}$.

Thomas, D.M., Paillet, F.L., and Conrad, M.E., 1996, Hydrogeology of the Hawaii scientific drilling project borehole KP-1-

2. Groundwater geochemistry and regional flow patterns: Journal of Geophysical Research, v. 101, no. B5, p. 11,683-11,694.

-By Stephen B. Gingerich and Delwyn S. Oki

For further information contact:

District Chief

U.S. Geological Survey, WRD

677 Ala Moana Blvd., Suite 415

Honolulu, HI 96813 